\title{
Could the Greek Taxation Policy Pull the Economy from the Recession to Development?
}

\author{
Mihail N. Diakomihalis \\ Technological Educational Institution of Epirus \\ Greece \\ E-mail: diakomnisyros@gmail.com
}

Athina Politou

Freelancer Accountant

Greece

Received: June 28, 2018 Accepted: July 10, 2018 Published: July 17, 2018

doi:10.5296/ber.v8i3.13316 URL: https://doi.org/10.5296/ber.v8i3.13316

\begin{abstract}
This paper examines the tax system of Greece from 2002 to 2016, the changes that have been made to it and the structure and evolution over time of taxes compared to GDP components and particularly to investments. Also, the impact of taxes on investments by category, is being studied. Examining the changes in taxes and investment in Greece for the 15year period, a negative relationship among them was found, as there was an increase in taxes and a reduction in investment. This is more profound in the period of the crisis 2010-2016, when taxation was increased (compared to pre-crisis years, 2002-2009) leading to an even greater reduction in investments in total economy. Considering the findings of our research, as well as those of previous studies, government and policy makers should realize that the reduction in the tax burden can bring an increase in investments by business and households, and that investments is the only route to drive the economy out of the recession.
\end{abstract}

Keywords: Taxation, Investment, Recession, Development, GDP, Greek economy

\section{Introduction}

Growth is the ultimate goal of each country's policy in order to overcome recession. Taxation is one of the most vital tools a government has to raise resources and meet its individual goals. Investments, and especially productive investments and research and development 
investments, are factors that past empirical researches have shown to be a determining factor of growth. Over time, various theories have been developed for the structure of taxation and its relationship to growth.

The concepts of development and taxation are multidimensional and their relationship is determined by various factors. The role of taxation on economic development focusing on the fiscal policy applied in Greece over the last 15 years and its impact on public revenues from taxes and on GDP, is the subject of the present study. First, a literature review regarding the relation of taxes with the fiscal policy and economic development in order to identify the effects of different kind of taxes according to the particular characteristics of each economy, as well as the current updates in the applicable tax policies, is accomplished. The basic characteristics of the Greek tax system and the problems presented both in relation to the tax collection and to strengthening the competitiveness of the economy, are also research subjects of this paper.

In the empirical work we examine the relationship between tax revenues and GDP in Greece over the last fifteen years (2002-2016). The intertemporal development of tax revenues in Greece along with the structure of the total taxes has been studied. The intertemporal evolution of GDP for the same period and its structure on the basis of the income approach, along with investments and the R\&D investments as a percentage of GDP are also examined. The intertemporal evolution of tax revenues as a percentage of GDP is also analyzed. The relationship between the rate of GDP change and in particular the rate of taxes evolution and the rate of investment modification (total and per category) are the factors examined for the impact of taxation on the development.

In order to examine the role of taxation on economic development we consider investments as the basic parameter of growth, which has been confirmed by empirical investigations that have positive correlation with the GDP changes. Thus, the research focuses on the relationship between tax revenues and investments, both overall and by category, i.e. public investments, households' investments and businesses' investments. Examining comparably the intertemporal development of taxes and investments as percentage of GDP, and the relationship of the annual changes, we expect to reveal useful conclusions on how taxation affects investments and consequently development. From this study we aim to find the degree of tax impact on economic development of Greece and the fulfilment of the fiscal policy objectives applied before and after the financial crisis of 2008.

\section{Literature Review}

One of the first studies of taxation effects on economic development is that of Marsden in 1983. Combining per two, ten countries with data of the '70s, examined for each country income per capita with different relations of total tax revenues or the average tax rates. The investigation revealed that countries with low taxes have higher rates of growth, compared with the countries that had higher taxes (Marsden, 1983).

Koester and Kormendi, using data from 63 countries, searched in 1989 the impact of the average and marginal tax rates at the levels and the change in the economic activity. They 
found that there was a significant negative impact on the pace of economic growth from both the average tax rates and the marginal tax rates. Finally concluded that reducing the marginal rate of income tax by 10 percent could lead to increase of $15.2 \%$ on the GDP of the less developed countries and an increase of $7.4 \%$ on GDP of the most developed countries. Besides they found that maintaining constant average tax rates, and reducing marginal tax rates, is associated with an upward direction shift in the growth of the economy (Koester \& Kormendi, 1989).

Engen and Skinner in 1996 studied the effect of tax reform on the long-term rate of growth in the US economy. The results of their research showed a moderate degree of influence, and in particular $0.2-0.3 \%$ change in the rate of growth, as a result of a major tax reform, namely the reduction of marginal tax rates by $5 \%$ and the average tax rates by $2.5 \%$ (Engen \& Skinner, 1996).

Gordon and Lee in their research investigated how the fiscal policies affect the growth rate of a country, using statistical data from 1970 to 1997, believing that tax policy could affect the rate of GDP growth. They observed that during periods of high growth there would be a greater demand for new infrastructure and public expenditure, therefore taxes should increase to finance the increase in demand from these programs (Gordon \& Lee, 2005). Also noted that countries with lower levels of initial per capita GDP had more rapid growth.

Gordon and Lee believe that the lower rate of corporate taxation can create higher percentage of capital investments and more knowledge through increased business. In conclusion, the rate of corporate income tax is related significantly negative with the per capita growth rate (Gordon \& Lee, 2005).

Widmalm in 2001 found that the proportion of tax revenue resulting from the personal income taxation has a negative correlation with the economic development. The reliability of the result is confirmed by the sensitivity analysis, where the author systematically checks other key determinants reasonable growth factors (Widmalm, 2001).

Arnold (2008) found that the property taxes are more friendly for the development of the economy, followed by excise and then from personal income tax. Besides, it appears that business income taxes have the most negative effects on growth (Arnold, 2008). Bernardi in 2013 found that the profits from a tax offset (from direct to indirect taxes) does not appear to be as simple as claimed in previous studies. On the other hand, he provides that a shift of the tax may exacerbate the economic recession which extends across the European Union, especially as a result of the general adoption of restrictive budgetary policies in almost all member countries (Bernardi, 2013).

Canavire-Bacarreza, Martinez-Vazquez and Vulovic assessed in 2013 the effect of divergent fiscal instruments for the development of Latin America countries and they found that the income tax is not the expected negative impact on economic growth (Canavire-Bacarreza, et al., 2013). Tanchev (2016) found that the progressive income tax had a positive impact on the development of Bulgaria for the period 2004-2012 (Tanchev, 2016). The conclusion in the study on the relationship between taxation and development of $28 \mathrm{EU}$ member states for the 
period 1996-2013, was that the tax structure based on selective excise taxes, taxes on income and on assets, strengthens the economic development (Stoilova, 2017).

Baranová - Janíčková (2012) in their study for the European Union countries for the period 1998 to 2010 concluded that the reduction of the tax burden on business accelerates economic development, (Baranová \& Janíčková, 2012). In the research for hotels in a main tourist destination of Greece, the impact of the tax (corporate taxes, municipal taxes, indirect taxation, etc.) on the competitiveness of hotel businesses was examined. The investigation showed that the high tax burden affects the competitiveness of hotels and entail a reduction in demand and tourists' preference for more competitive destinations (Vlachos, et al., 2011).

Studying alternative impacts of taxation on economic growth, the tax compliance of small and medium-sized tourism enterprises in Georgia has been examined, and it was found that the business environment is enhanced by the reduction of tax burden and the provision of tax incentives to investors, while it also increases the voluntary tax compliance (Helhel \& Varshalomidze, 2015).

For a better understanding of the fiscal policy applied in Greece, it is appropriate to examine the intertemporal evolution of tax rates and, in particular, of the business income tax and on personal income tax, as well as on the VAT.

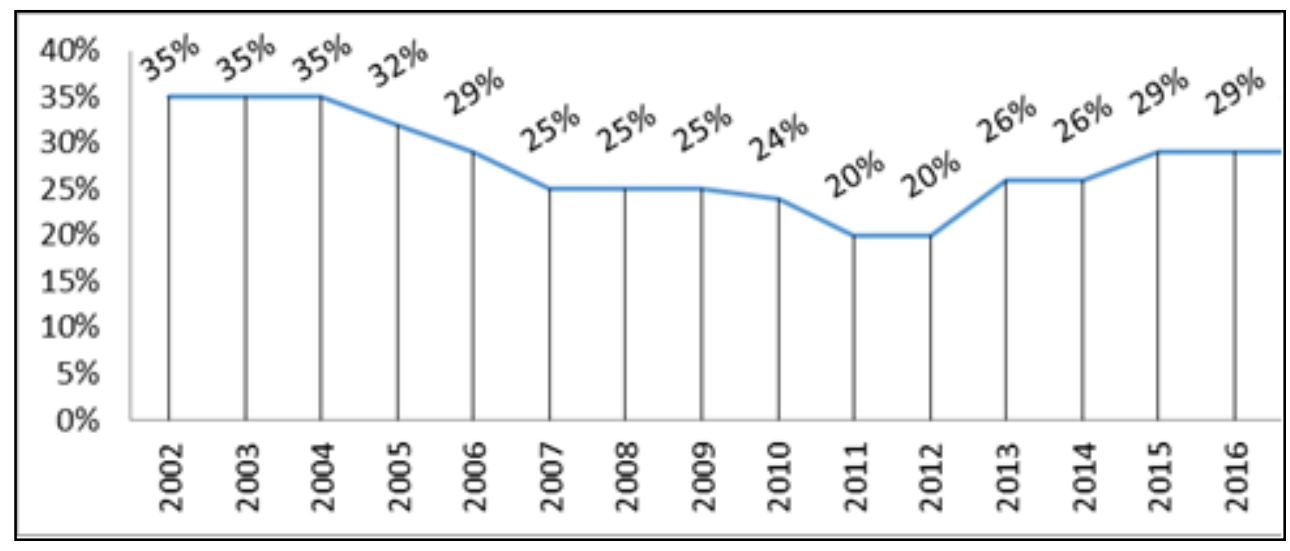

Figure 1. Income Tax Rates for S.A. and LTD companies, 2002-2016

Source: https://www.taxheaven.gr/pages/klimakes

As shown in the above Figure 1, there has been a clear attempt to reduce the taxation of the profits of S.A and LTD companies until 2012. The company profits were taxed for the years $2002-2004$ at a rate of $35 \%$ which gradually reduced to $25 \%$ in 2007 , and maintained until 2009. In 2010 legal entities were taxed with $24 \%$, while the rate has been reduced to $20 \%$ in the following two years, 2011-2012. Since then there has been an increase in the taxation rate ending to $29 \%$ tax on the profits of SA and LTD companies.

Regarding the physical persons' taxation there was an attempt to tax relief until 2012, by increasing the nontaxable income scale and widening the tax scales. In 2007 the tax scales remained 4 , but the nontaxable income had risen from $7.400 €$ to $12,000 €$ and the highest tax 
rate was $40 \%$, applied to income exceeding $75,000 €$ instead of $23.400 €$ which was applied in 2002. The nontaxable income had remained to $12,000 €$ in 2010 but the tax scales increased to 9 while the highest tax rate increased to $45 \%$ for income over $100,000 €$. The last two years, personal income tax scale remained steady, having four tax scales. The minimum tax rate is $22 \%$ applied to income up to $20,000 €$ (with maximum valid tax reduction of $1,900 €$ if expenditure has been paid by debit or credit cards), while for incomes over $40,000 €$ the tax rate is $45 \%$.

The rates of VAT showed over time significant rise while the categories of goods and services as well as the geographical areas of the country with reduced and low VAT rates, have been restricted. Characteristic is the VAT rate on food, which has more than doubled from the beginning of VAT application in Greece. The imposed VAT for food was 6\% in 1987 and increased to $13 \%$ in 2011. The reduced VAT rate of $13 \%$ was applied in accommodation until 2011 , but after 2011 was replaced by the standard rate of $23 \%$. The standard rate over time has increased from $18 \%$, to $24 \%$, while the high rate of $36 \%$ which was applied to petroleum products and tobacco, alcoholic drinks, etc has been abolished (Kitsopoulos, 2016).

\section{Methodology}

To investigate the degree of taxes impact on the growth of the economy, we examine the relationship of taxes and investments, expressed as percentages of GDP, along with the annual rate of change of the two values. We have applied qualitative comparative analysis (QCA) which is a data analysis technique for determining which logical conclusions a data set supports. The analysis begins with listing and counting all the combinations of variables observed in the data set, followed by applying the rules of logical inference to determine which descriptive inferences or implications the data supports (Charles Ragin, 1987). This analysis is carried out both overall as well as on the basis of individual categories of investments made by households, businesses and the government. Since investments, especially investments in Research and Development (R\&D) are key elements for the development of an economy, their trend in terms of GDP might be able to reveal useful information both about the factors which have influenced the variation of GDP, and about the conditions obtaining in Greece in the field of investments, which form the basis for the development of the economy. Finally, the relationship of income taxes of legal entities and business investments are examined. Since productive investments is the driving force for the business development, the study in particular of the corporate tax rate and the degree of investment by businesses is expected to lead to useful conclusions.

The financial data for the purpose of this research were obtained by the database of official statistical authorities and in particular from the database of ELSTAT (Greek Statistics Services) and Eurostat. For the impact of taxes on the economic development of Greece, the structure of the taxes and GDP are examined, while the tax rates to GDP and the relationship of investments to taxation have been studied comparatively. In particular, the sources of the individual data, the period of study and the values to be examined are:

1. Eurostat: all taxes and levies, total tax revenue in absolute values (euros), the structure of the taxes (taxes on production and imports, taxes on income and wealth, social security 
contributions and other taxes) for the period 2002-2016.

2. Eurostat: the structure of the taxes on products and of VAT as a percentage of total taxes for the period 2002-2016.

3. Eurostat: the structure of income taxes in relation to the total taxes for the period 2002-2016.

4. ELSTAT: the GDP expressed in euros (market prices) for the period 2002-2016.

5. ELSTAT: the components of GDP on the basis of the income approach in euros for the period 2002-2016.

6. Eurostat: investment per category as a percentage of GDP over the years 2002-2016.

7. Eurostat: investments in R\&D per category as a percentage of GDP over the period 2002-2016.

8. Eurostat: the proportion of individual tax revenue to GDP for the period 2002-2016.

9. Intertemporal comparison of taxes and investments as a percentage of GDP and annual percentage change.

10. Intertemporal comparison of taxes and investments per category, as a proportion of GDP and their annual change.

11. Intertemporal comparison of households' income tax and of households' investments as a percentage of GDP and their annual change.

12. Intertemporal comparison of business income tax and corporate investment as a percentage of GDP and their annual change.

13. Calculation and comparison of average change in total taxes, corporate taxes, the total investment and investment per category, for the total period considered, 2002-2016 and by the sub-periods, before and during the financial crisis. The period before crisis is 2002-2009 and during the crisis is 2010-2016.

\section{Intertemporal Structure of Taxes 2002-2016}

According to the classification of taxes in the European Union (ESA 2010), which has been adopted also by Greece, the distinction of taxes includes three main categories. Taxes on production and imports, which are primarily indirect taxes, current taxes on income and wealth, referring to direct taxes, and social security contributions (Eurostat, 2017).

For a better understanding of the Greek fiscal policy, it is appropriate to examine the intertemporal evolution of tax rates and, in particular, the income tax on legal entities and physical persons and the VAT. 


\section{Macrothink}

Business and Economic Research

ISSN 2162-4860

Table 1. Tax scales of personal income tax 2002-2017

2018, Vol. 8, No. 3

\begin{tabular}{|c|c|c|c|c|c|c|c|c|c|c|c|c|c|c|c|c|c|c|c|c|c|c|c|c|c|c|c|c|}
\hline In 0,000 & 5 & 7,4 & 8,4 & 10 & 11 & 12 & 13 & 13,4 & 16 & 20 & 22 & 23 & 23,4 & $>23,4$ & 25 & 26 & 30 & 32 & 40 & $>40$ & 42 & $>42$ & 60 & 75 & $>75$ & 100 & $>100$ & Scales \\
\hline 2002 & & 0 & 5 & & & & & 15 & & & & & 30 & 40 & & & & & & & & & & & & & & 5 \\
\hline 2003 & & & & 0 & & & & 15 & & & & & 30 & 40 & & & & & & & & & & & & & & 4 \\
\hline 2004 & & & & 0 & & & & 15 & & & & & 30 & 40 & & & & & & & & & & & & & & 4 \\
\hline 2005 & & & & & 0 & & 15 & & & & & 30 & & 40 & & & & & & & & & & & & & & 4 \\
\hline 2006 & & & & & 0 & & 15 & & & & & 30 & & 40 & & & & & & & & & & & & & & 4 \\
\hline 2007 & & & & & & 0 & & & & & & & & & & & 29 & & & & & & & 39 & 40 & & & 4 \\
\hline 2008 & & & & & & 0 & & & & & & & & & & & 27 & & & & & & & 37 & 40 & & & 4 \\
\hline 2009 & & & & & & 0 & & & & & & & & & & & 25 & & & & & & & 35 & 40 & & & 4 \\
\hline 2010 & & & & & & 0 & & & 18 & & 24 & & & & & 26 & & 32 & 36 & & & & 38 & & & 40 & 45 & 9 \\
\hline 2011 & 0 & & & & & 10 & & & 18 & & & & & & & 25 & & & 35 & & & & 38 & & & 40 & 45 & 8 \\
\hline 2012 & 0 & & & & & 10 & & & 18 & & & & & & & 25 & & & 35 & & & & 38 & & & 40 & 45 & 8 \\
\hline 2013 & & & & & & & & & & & & & & & 22 & & & & & & 32 & 42 & & & & & & 3 \\
\hline 2014 & & & & & & & & & & & & & & & 22 & & & & & & 32 & 42 & & & & & & 3 \\
\hline 2015 & & & & & & & & & & & & & & & 22 & & & & & & 32 & 42 & & & & & & 3 \\
\hline 2016 & & & & & & & & & & 22 & & & & & & & 29 & & 37 & 45 & & & & & & & & 4 \\
\hline 2017 & & & & & & & & & & 22 & & & & & & & 29 & & 37 & 45 & & & & & & & & 4 \\
\hline
\end{tabular}

Source: https://www.taxheaven.gr/pages/klimakes

Table 2. V.A.T. rates 1987-2016

\begin{tabular}{|l|l|l|l|l|l|l|l|}
\hline Categories & VERY LOW & REDUCED & REDUCED & ACCOMMODATION & NORMAL & HIGH \\
\hline $\begin{array}{l}\text { Example } \\
\text { From }\end{array}$ & To & $\begin{array}{l}\text { Books, Newspapers, } \\
\text { Magazines }\end{array}$ & $\begin{array}{l}\text { Refreshments } \\
\text { (consumption in and out) }\end{array}$ & Food & Accommodation & Services & $\begin{array}{l}\text { Oil products, Alcohol, } \\
\text { Cigarettes, etc. }\end{array}$ \\
\hline $1 / 1 / 1987$ & $7 / 8 / 1992$ & 3 & 6 & 6 & 6 & 18 & 36 \\
\hline $8 / 8 / 1992$ & $31 / 3 / 2005$ & 4 & 8 & 8 & 8 & 18 & 18 \\
\hline $1 / 4 / 2005$ & $14 / 3 / 2010$ & 4,5 & 9 & 9 & 9 & 19 & 19 \\
\hline $15 / 3 / 2010$ & $30 / 6 / 2010$ & 5 & 10 & 10 & 10 & 21 & 21 \\
\hline $1 / 7 / 2010$ & $31 / 12 / 2010$ & 5,5 & 11 & 11 & 11 & 23 & 23 \\
\hline $1 / 1 / 2011$ & $31 / 8 / 2011$ & 6,5 & 13 & 13 & 13 & 23 & 23 \\
\hline $1 / 9 / 2011$ & $31 / 7 / 2013$ & 6,5 & 23 & 13 & 23 & 23 & 23 \\
\hline $1 / 8 / 2013$ & & 6,5 & $13-23$ & 13 & 13 & 23 & 23 \\
\hline $1 / 6 / 2016$ & & 6 & 24 & 13 & 24 & 24 & \\
\hline
\end{tabular}

Source: Kitsopoulos E. (2016), http://www.abcit.gr/index.php/news-feeds/vat-greece-history 


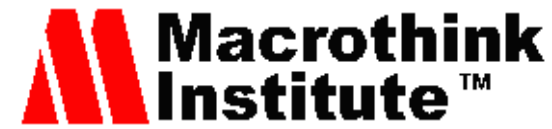

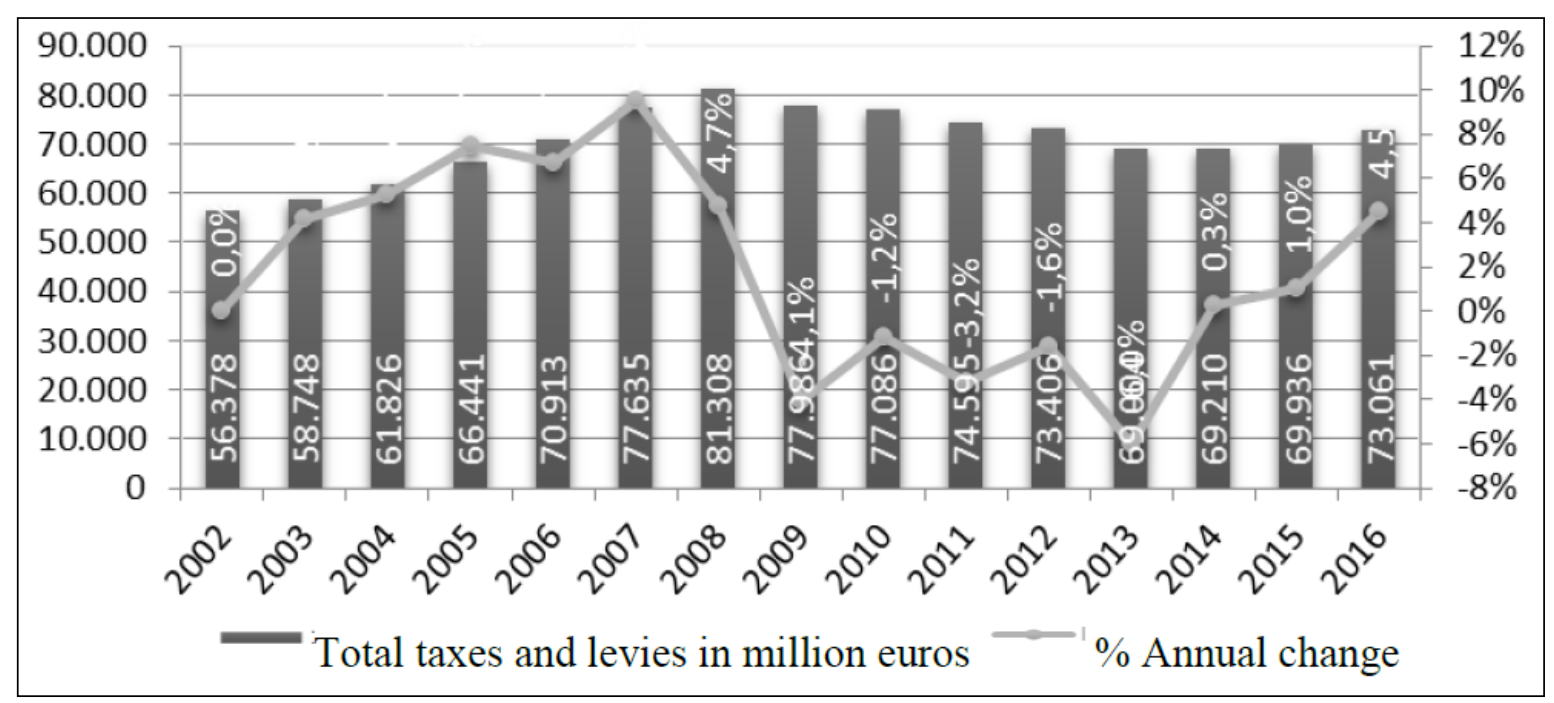

Figure 2. Total taxes and levies imposed in million euros \& \% change 2002-2016

Source: Eurostat, (2018), Government statistics,

http://ec.europa.eu/eurostat/web/government-finance-statistics/data/main-tables

As shown in the above Figure 2, the total tax revenues and levies, until 2008, had grown steadily, having increasing growth rates up to 2007. The first year of the international economic crisis, 2008, the total tax revenues of Greece, in absolute values, reached the highest in recent years, 81,3 billion euros. Since then and until 2013 the revenues have been gradually reduced, although the lower limit (in 2013), ranged around the 2006 revenue, i.e. about 69 billion in 2014-2015. Despite the fact that the overall tax revenues have increased, the increases were marginal, while in 2016, after an increase of $4.5 \%$, have reached about 73 billion euros.

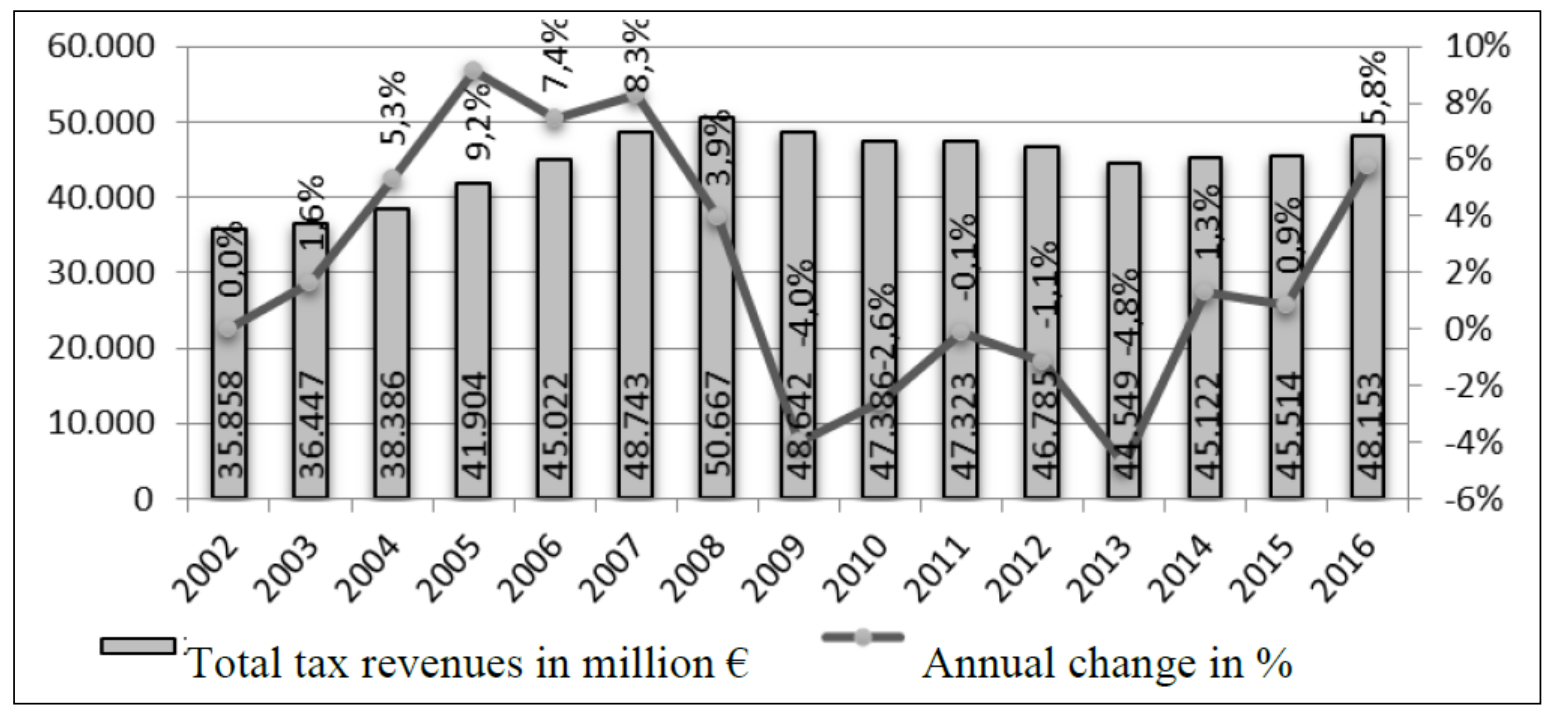

Figure 3. Total tax revenues in million $€ \& \%$ change $2002-2016$

In respect to total taxes imposed we noticed (Figure 3) that they have shown exactly the same 


\section{Macrothink}

Business and Economic Research

ISSN 2162-4860

2018, Vol. 8, No. 3

intertemporal evolution with the tax and insurance revenues, but with different evolution rates.

As shown in the Figure 4, it should be noted that there is a different trend in the course of the individual taxes, before and after 2010. In particular, there is a gradual increase in the contribution of social levies in total and overall reduction in direct and indirect taxes, with variations between them every year, until 2010. After 2010 there is a gradual reduction of social security contributions as a whole, but also a clear trend of increasing taxes on products and imports. There is an obvious increase in income taxes, for the years 2012-2013, but their contribution to the whole is reduced thereafter.

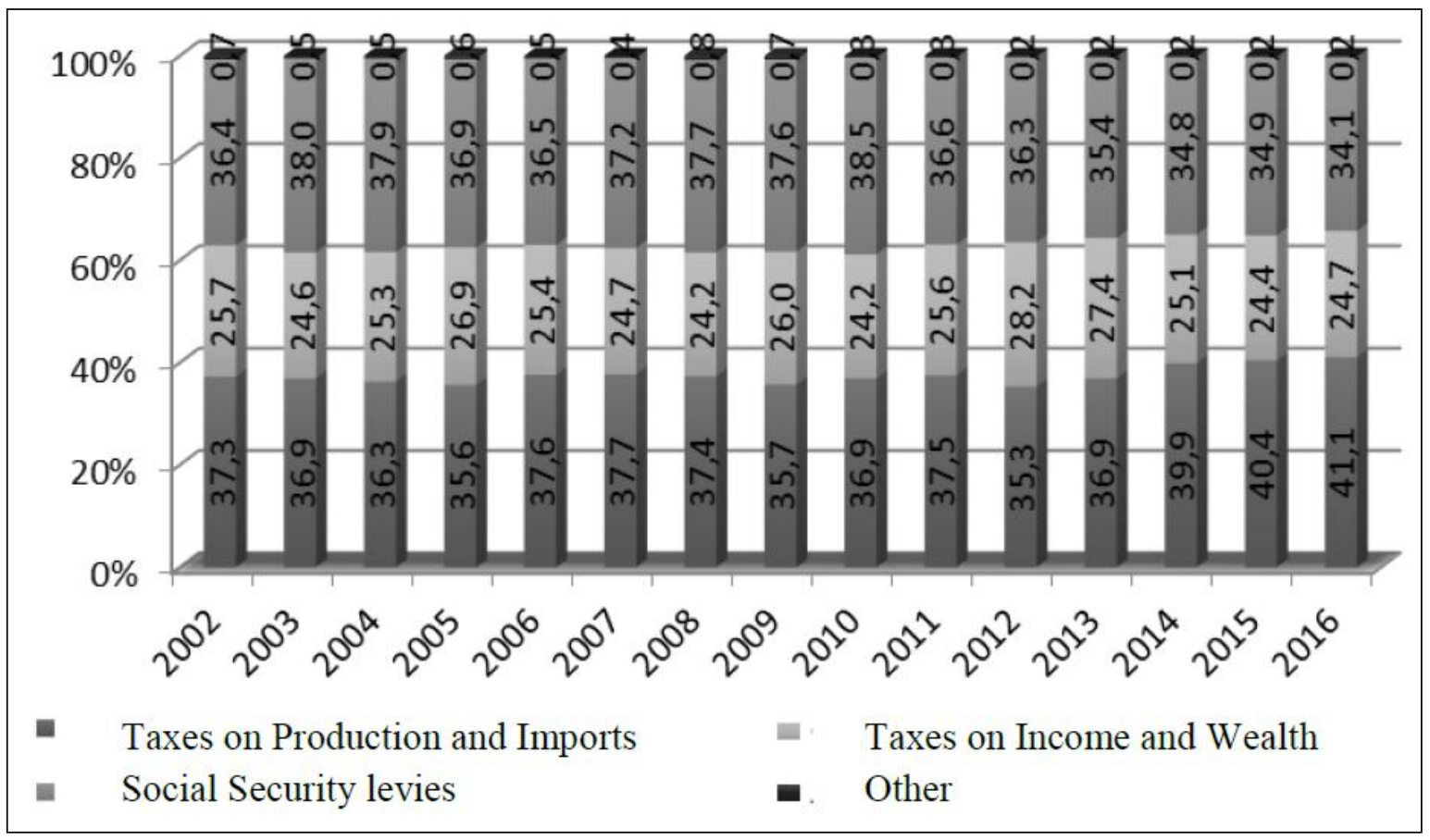

Figure 4. Contribution of basic tax categories to total taxes

Regardless of any small or larger variations, characteristic of the taxes structure is that taxes on income and wealth held the smaller proportion, approximately a quarter of total taxes. 


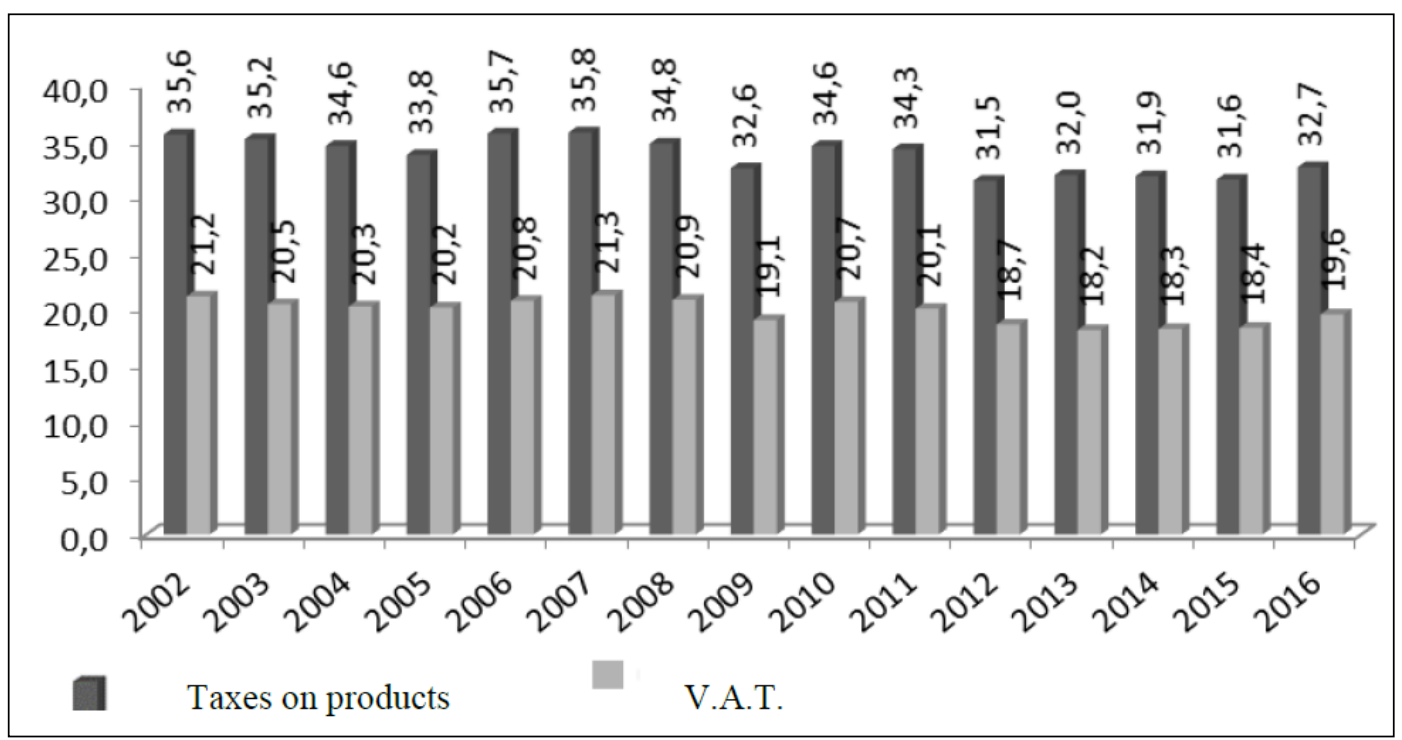

Figure 5: Proportion of taxes on products and V.A.T. on total taxes

In 2002, the taxes on products accounted for $35.6 \%$ of the total taxes, while in 2007 the proportion increased to $35.8 \%$. The last five years the overall ratio has been reduced, varying from $31.5 \%$ in 2012, up to $32.7 \%$ in 2016. Most of the taxes on products is the Value Added Tax, which counts for $58 \%-59 \%$ of taxes on products for all years, with the exception of 2013-2014 when it was two percentage points less. In total of taxes the proportion of VAT is around $20 \%$.

The personal income tax follows a steady course until 2009, then it is reduced in 2010- 2011 and reaches the maximum value of 18.0 billion in 2012, to follow a decreasing trend until 2016 to 14.0 billion euros.

Taxes on employees and pensioner income are those who contribute more to the total income taxes over time. The trends of business income taxes or corporate profits is moving in the opposite direction, reaching in 2012 the minimum of 2.8 billion.

\section{Intertemporal evolution of GDP 2002-2016}

The GDP data expressed in market prices and in million euros (provisional data for the period 2011-2016) are drawn from a database of ELSTAT, revised on the basis of the European Union Regulation 549/2013 (ESA 2010) (ELSTAT, 2017). 


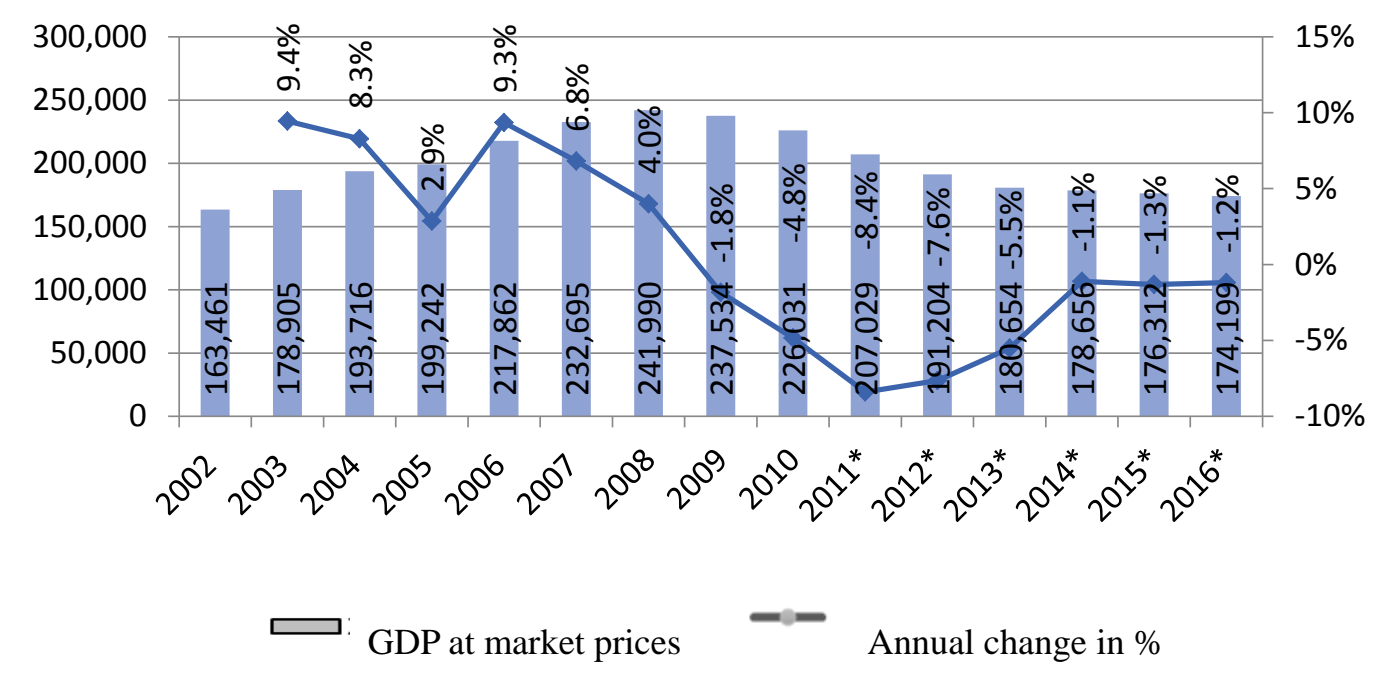

Figure 6. GDP at market prices and yearly change 2002-2016

The Greek GDP from 2002 to 2008 had a significant increase, with annual changes over 9\% (9.4\% in 2003 and 9.3\% in 2006). The GDP increased from 163,5 billion euros in 2002 to 242 billion euros in 2008, i.e. an overall increase of around 48\%. From 2009 onwards there is a downward trend, with significant reductions in 2011 (-8.4\%) and $2012(-7.6 \%)$. The last three years the negative rate of change has mitigated and the GDP in 2016 was 174,2 billion euros, approximately at the level of 2003.

For the study of the Greek GDP structure we used the income approach, i.e. the components of the compensation of employees, gross operating surplus/ gross income, taxes on production and imported goods less subsidies (Eurostat, 2016).

Among the incomes structuring the GDP over time the component with the greatest contribution is the gross operating surplus, followed by the compensation of employees and last by the taxes on production and imports. The first two components, while were steadily increasing up to the beginning of the crisis, in the years after show a significant decline, especially the gross operating surplus, since compensation for employees in the past four years does not show significant change. Taxes on products and imports contribute less to GDP and up to 2008, showing an ascending route while after 2008 begun to fell until 2013, and since then show a slight increase. Subsidies in general show a constant course almost throughout the period under consideration. In 2016 employees' compensation was 58.4 billion euros, gross operating surplus of 90 billion, taxes on products and imports 30.2 billion and subsidies of 4.4 billion euros. 


\section{Macrothink}

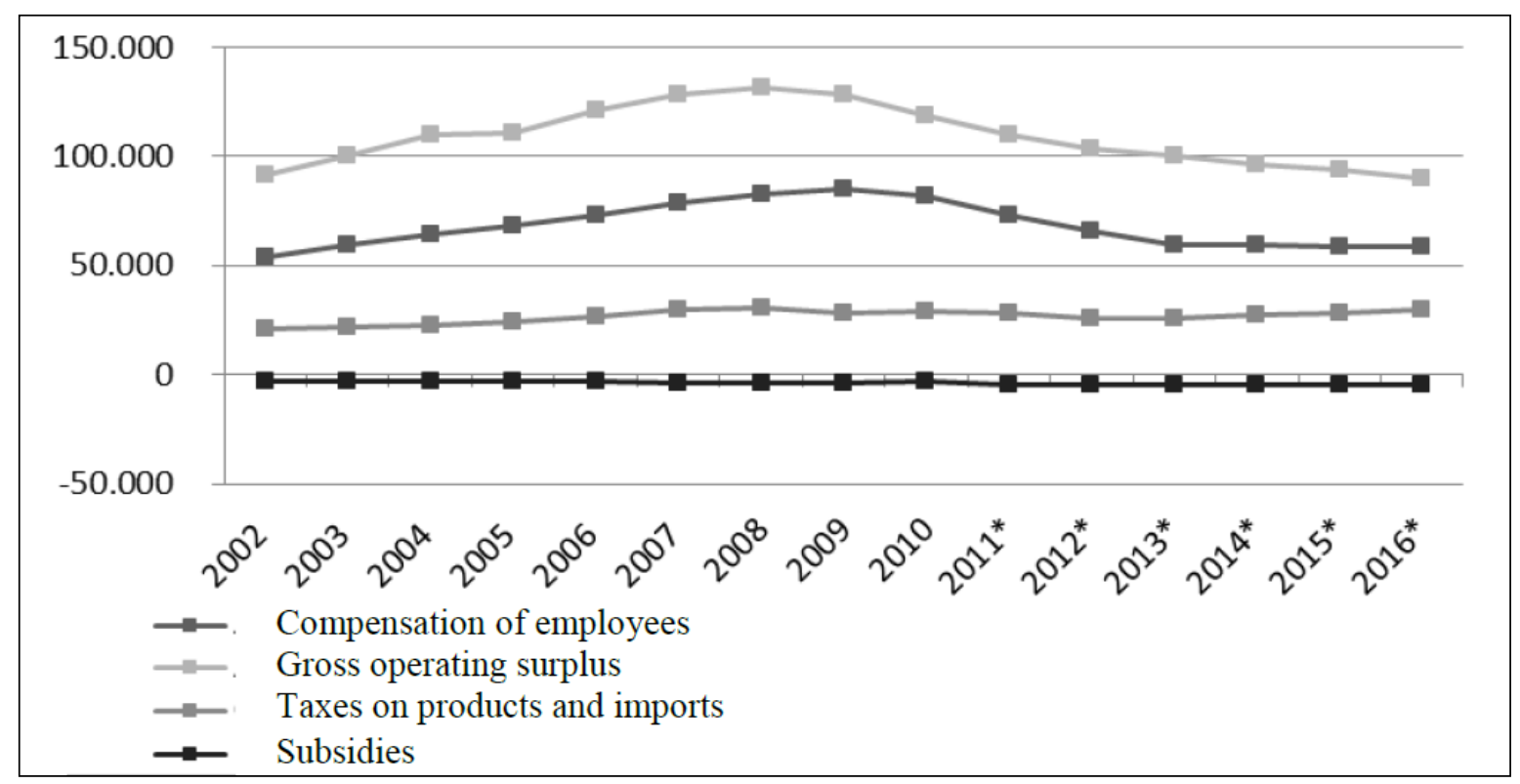

Figure 7. Components of GDP

For better understanding of each component's contribution on the GDP, their relative proportion is displaced in Figure 8. In 2008 the gross operating surplus was 54.5\% of GDP while in 2016 the rate decreased to $51.7 \%$. The employees' compensation was $36.3 \%$ of GDP in 2010 , but declined to $33.5 \%$ the 2016 . The taxes on production and imports despite the fact that have decreased after the crisis, successively increase their proportion reaching $17.3 \%$ of GDP in 2016, because the decrease in the other two components was greater.

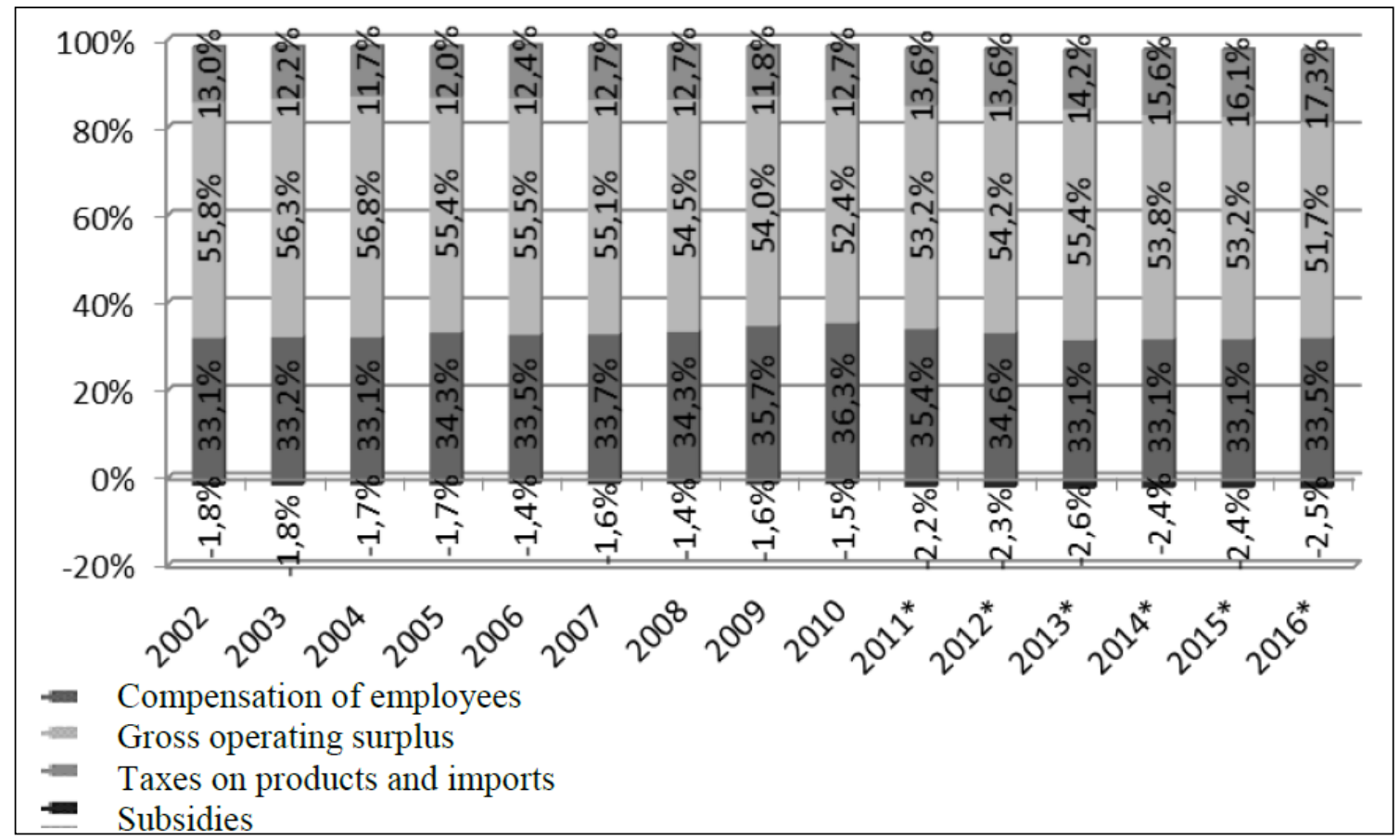

Figure 8. Proportion of components on GDP 


\section{Investments}

The intertemporal evolution of investments and of the R\&D investments as a percentage of GDP in Greece from 2002 to 2016 is examined individually for enterprises, government and households. The period before the economic crisis, investments as part of the total economy, despite the fact of fluctuations, had an upward trend, given the increase in GDP. In 2007 investments were accounted $26.01 \%$ of GDP. From 2008 onwards there has been a significant drop of investments to $11.74 \%$ of GDP in 2016. As shown in the below Figure 9, the increase in investments in the period before the crisis is mostly due to the rise in households' and businesses investments. The investments of households up to 2008 exceeded $10 \%$ of GDP, while they counted for $13.33 \%$ of GDP in 2007, almost half of the total investments. The business investments in 2002 constituted $8 \%$ of GDP and the succeeding years showed a turning point, interrupted by an increase of $7.84 \%$ of GDP in 2007. The least participation of investments in GDP until the crisis of 2008 is that of the government sector, ranging primarily from $4.5 \%$ to $5.5 \%$ of GDP.

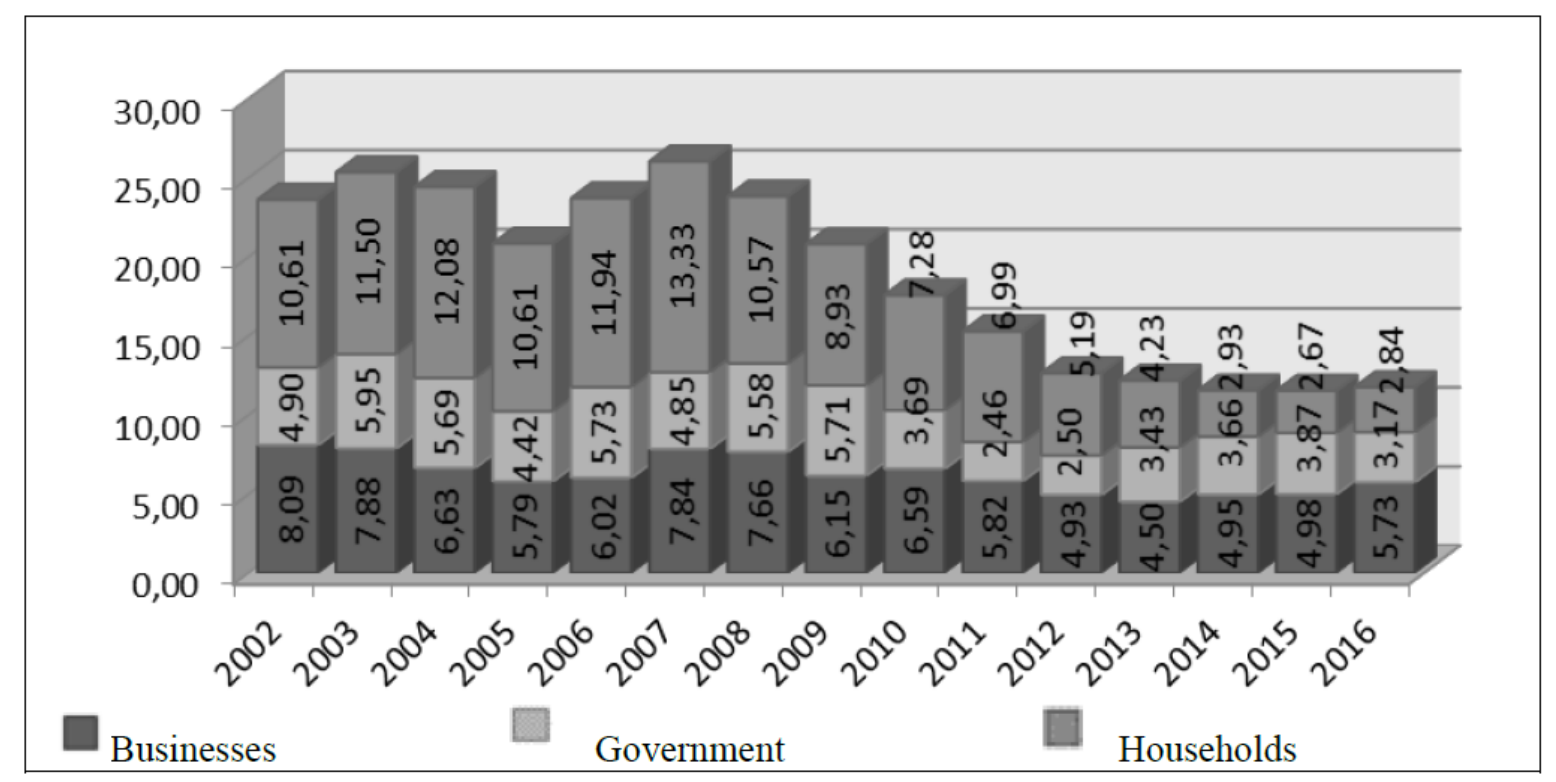

Figure 9, Investments as proportion of GDP 2002-2016

Source: Eurostat database, (2018), Investment to GDP ratio

The period during the economic crisis had a gradual reduction up to 2014, while the last three years, total investments are stabilized. The fall in households' investments is significant, declining to the lowest proportion of total investments in the last three years, below $3 \%$ of GDP. Slightly higher is government investments which counted in the years 2011-2012 to 2.5\% of GDP, while the last years vary between $3 \%$ and $4 \%$. The smallest decrease occurred in business investments, which seem to show a sign of recovery in 2016. In 2016 the business investments estimated $5.73 \%$ of GDP, the government $3.17 \%$ and households $2.84 \%$ of GDP.

Total investments in $\mathrm{R} \& \mathrm{D}$ in Greece are in a very low level, although over time a gradual rise 


\section{Macrothink}

Business and Economic Research ISSN 2162-4860 2018, Vol. 8, No. 3

as percentage of the GDP (with the exception of two years 2009-2010) is noted. In 2003, investments in R\&D constituted $0.55 \%$ of GDP, while in 2016 amounted to $1.01 \%$. Until 2008 the high education and business sectors have invested more in R\&D. Since 2009, there have been changes in the level of R\&D investments as a GDP percentage between the two sectors.

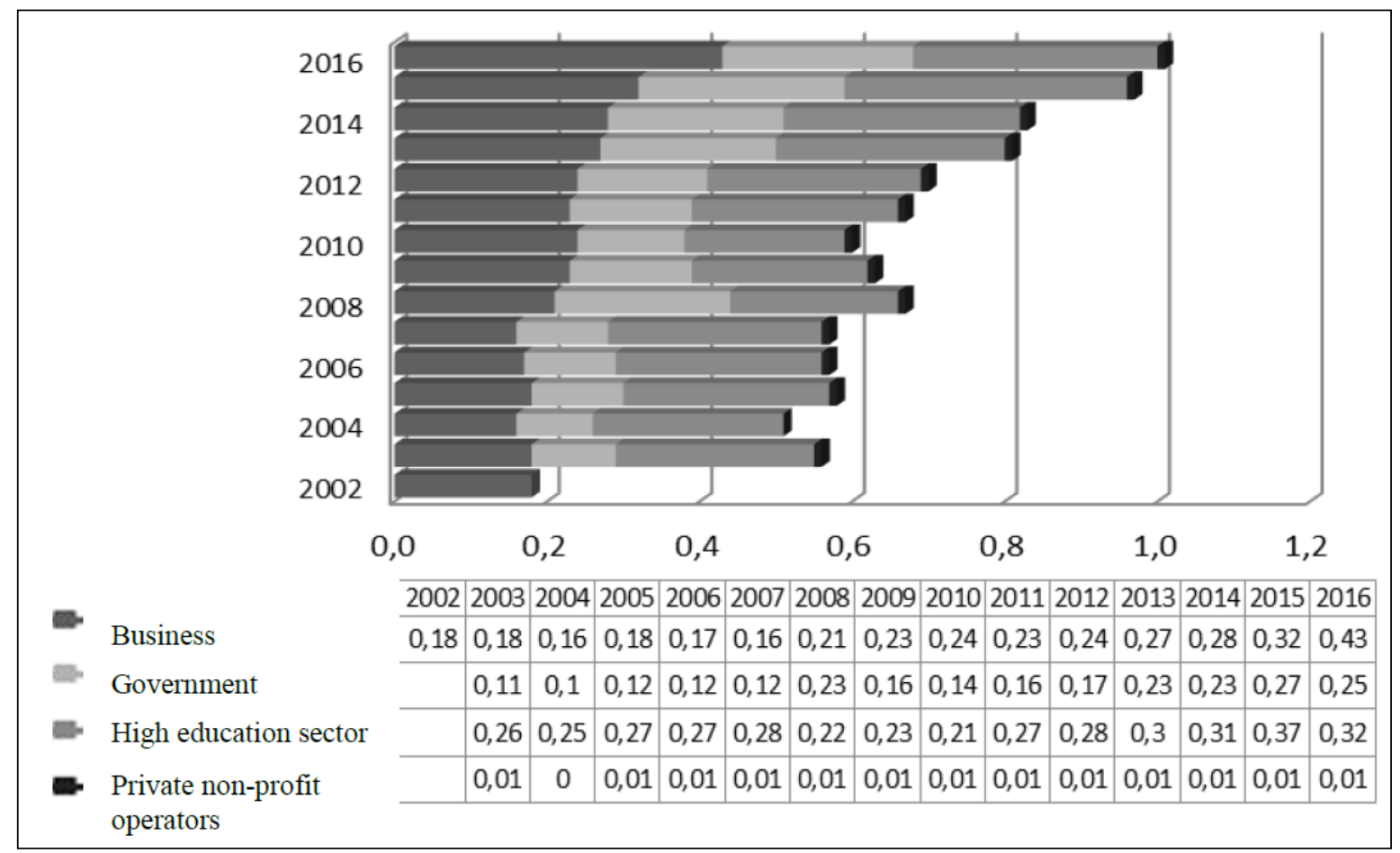

Figure 10. Investments in R \& D

\section{Correlation between Taxes and Investments}

The government expenditure on $\mathrm{R} \& \mathrm{D}$ noted increase, while the proportion of investments from the private sector non-profit operators has remained stable over time at $0.01 \%$ of GDP. In 2016 the percentage of R\&D expenditure as a proportion of GDP was at $0.43 \%$ for the business, $0.32 \%$ of high education sector and $0.25 \%$ of the government.

The relationship between taxes and investments is negative over time. According to the linear trend in the two sizes in the Figure 11, it should be noted that over time the taxes increase, while investments in the economy as a whole are reduced. From 2012 onwards the total taxes as a proportion of GDP exceed the ratio of investment to GDP. 


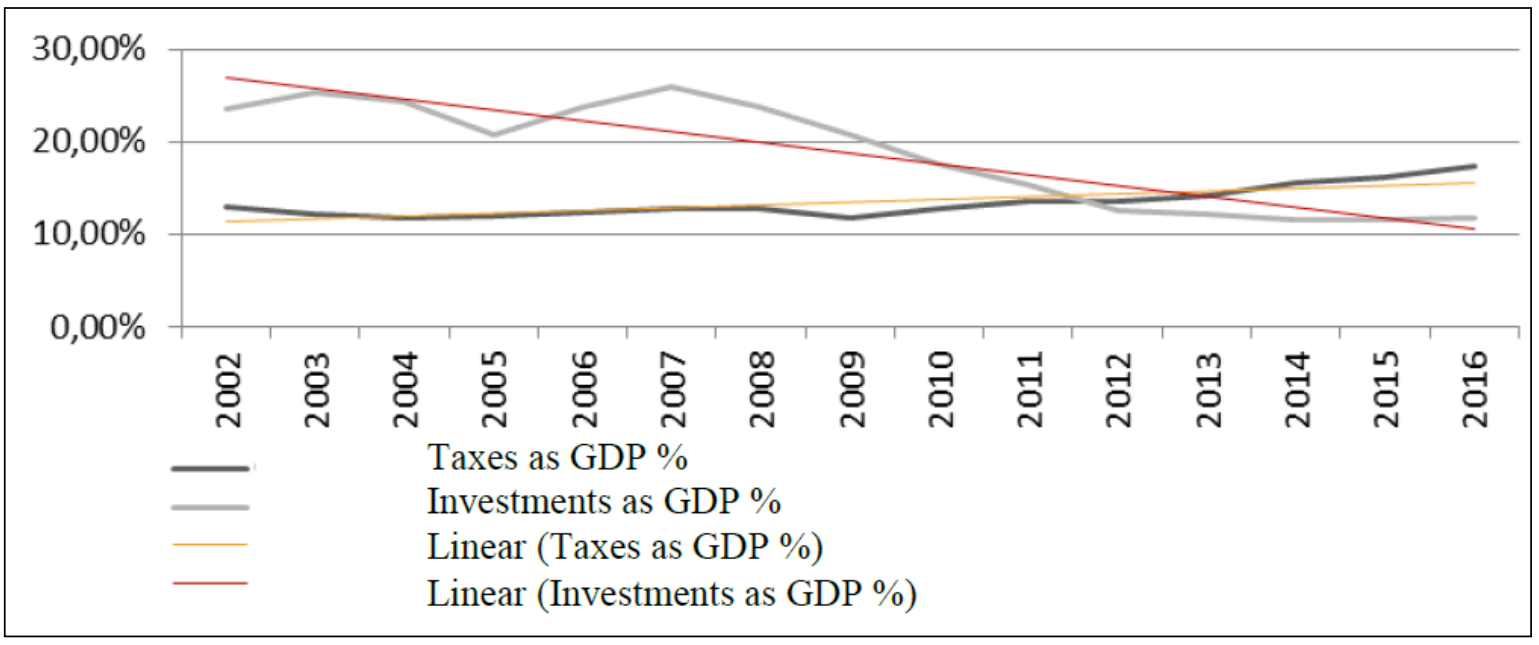

Figure 11. Intertemporal evolution of taxes and investments as \% of GDP

As shown on Figure 12, before the economic crisis the rate of investments' change in Greece has been fluctuated. For example, in 2005 the investments compared to the previous year decreased by $14.63 \%$ while in 2006 increased by $13.73 \%$. At the same time, several variations occurred in tax revenues also, but the changes were much smaller, while there seems to be no match between the rate of change of the two sizes, since in certain years, investments seem to be negatively affected by the increase in taxes and in other years, changes are respective.

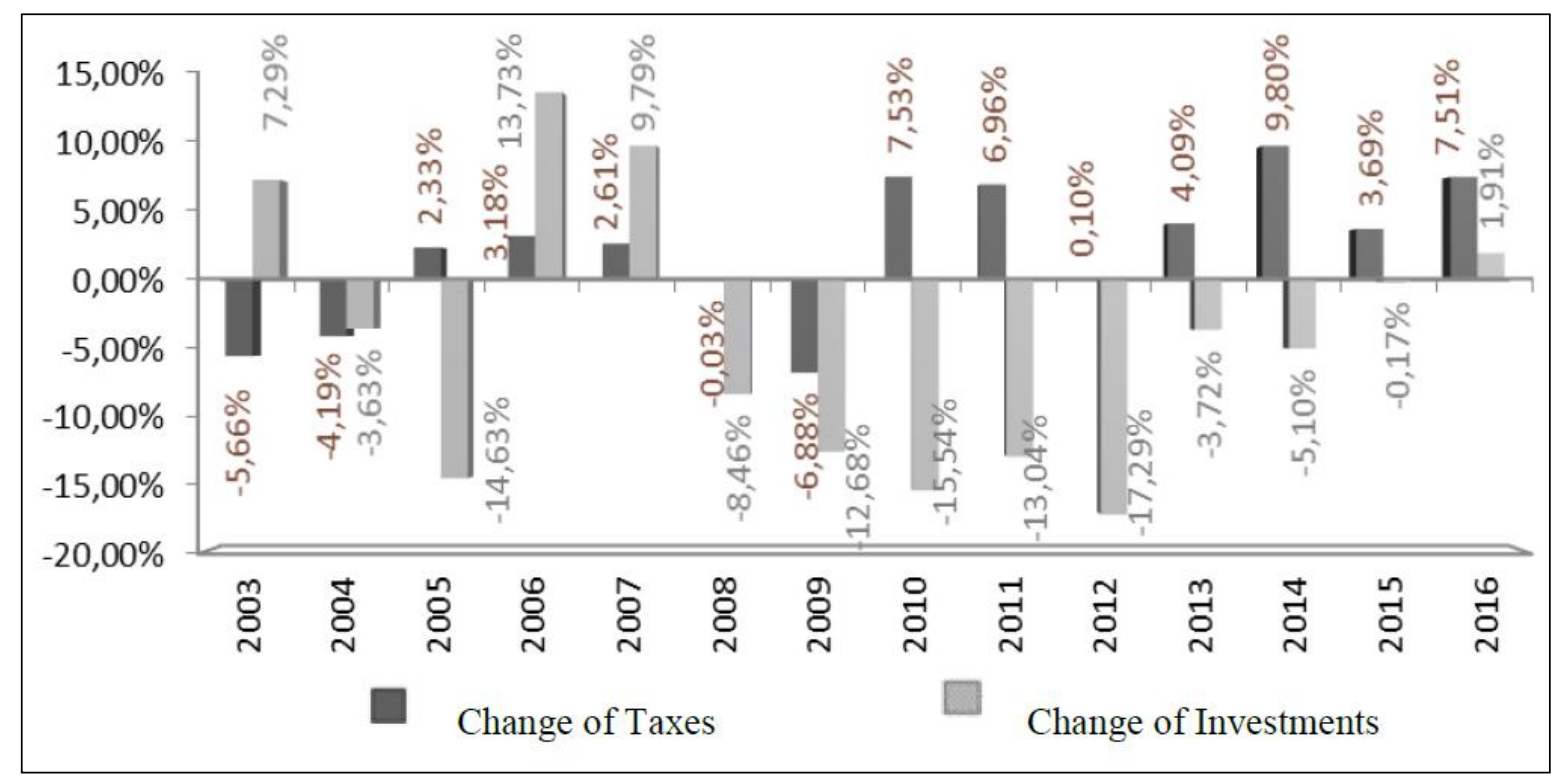

Figure 12. Annual change of Taxes and Investments

Taxes have shown steadily upward trend since 2009, in contrast with the investments which showed exactly the opposite course. More specifically, taxes increased by $7.53 \%$ and 


\section{Macrothink}

Business and Economic Research

ISSN 2162-4860

2018, Vol. 8, No. 3

investments decreased $15.54 \%$ in 2010 , while the tax increase was $6.96 \%$ and the reduction of investments was $13.04 \%$ in 2011. However, from 2014 and after the rate in investments is declining with the only increase in investments by $1.91 \%$ in 2016 .

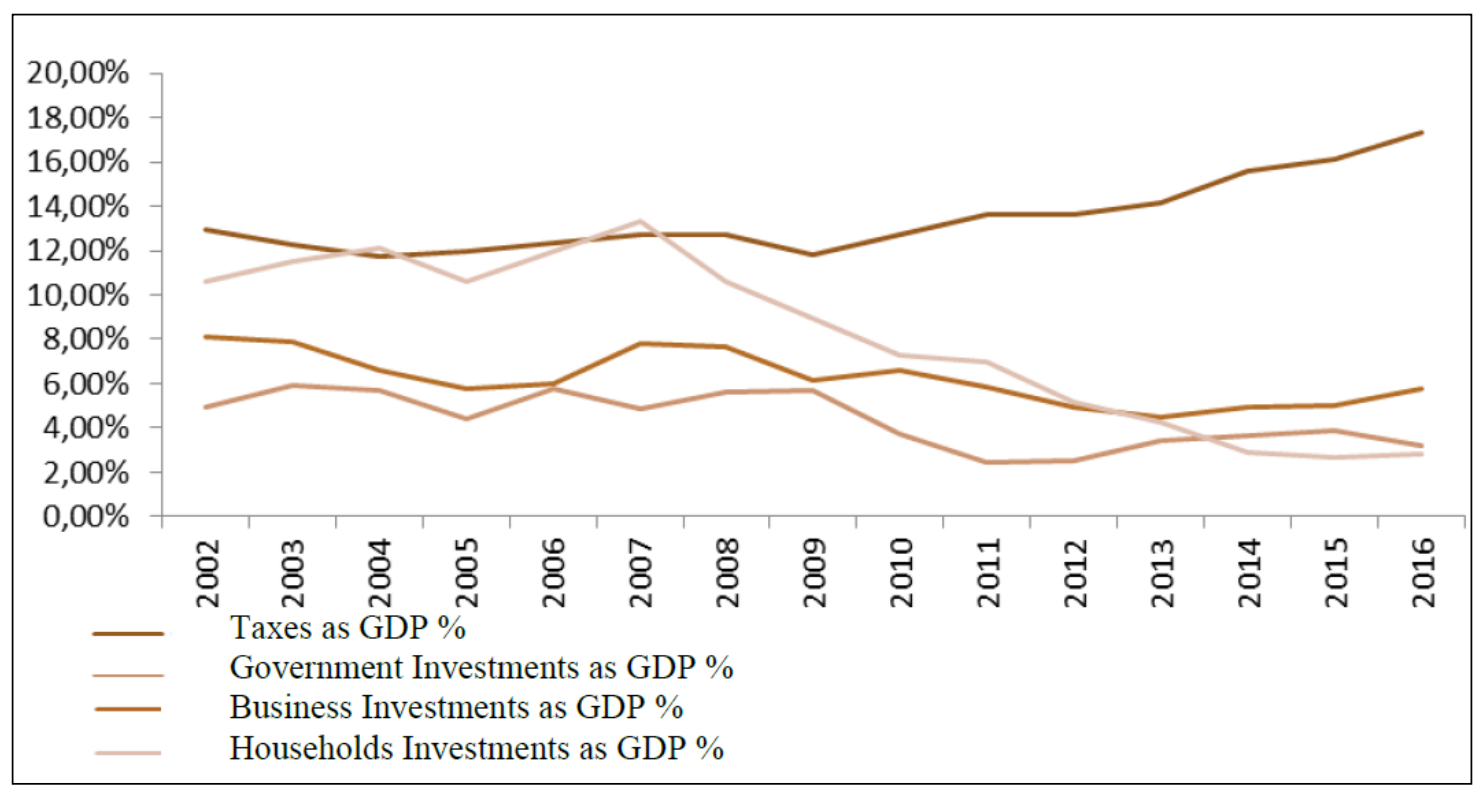

Figure 13. Intertemporal evolution of Taxes and Investments by category as GDP percentage

The intertemporal evolution and comparison of tax revenues and investments per category is presented in the above Figure 13. The highest decline from 2007 onwards occurred in the households' investments, while the government investments are lower than business investments, with the exception of the last three years when the government investments exceed those of the business.

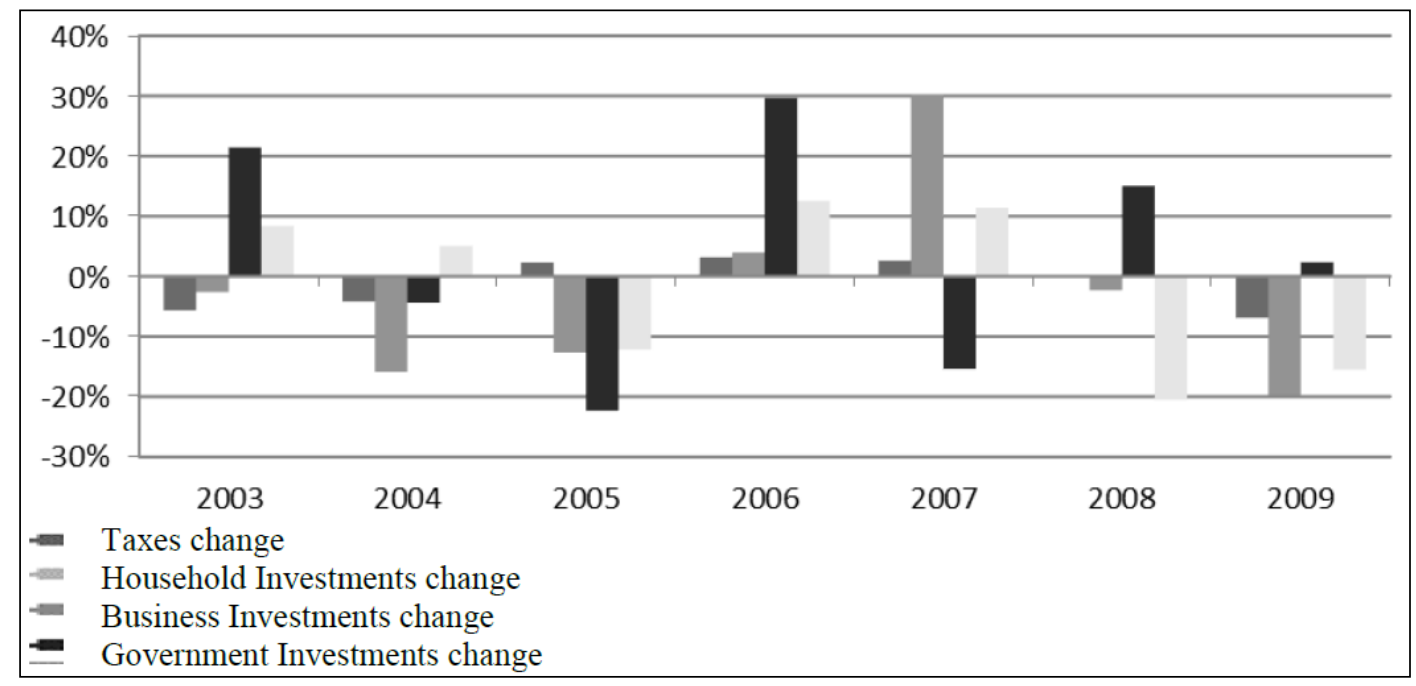

Figure 14. Annual change of Taxes and Investments by category 2003-2009 


\section{Mll Macrothink}

Business and Economic Research ISSN 2162-4860 2018, Vol. 8, No. 3

In the period before the crisis, it seems that the changes in businesses' investments have the same sign with the changes in taxes (with the exception of 2005), although the percentages of change differ significantly. In 2006 tax revenues increased by $3.18 \%$ and business investments by $3.97 \%$, while in 2007 the increase in tax revenues was $2.61 \%$ and that of investments $30.23 \%$. In 2009 taxes decreased by $6.88 \%$ while the business investment fell by $19.71 \%$. The government investments change in the opposite direction of the changes in tax revenue (with the exception of 2004 and 2006). Also, the change in the government investments is sufficiently higher than the change in tax revenue. Only in 2009 taxes decreased by $-6.88 \%$ while the government investments increased by $2.33 \%$.

During the crisis, the household investments had a negative rate of change in all years, except 2016, while corporate taxes changed positively. The government investments for the two years 2010-2011 were decreased on contrary to taxes increase, but in 2013 they increased very high, while the remaining years was less intense. The business investments had a negative rate of change only in the years 2011-2013 and moved to the opposite direction the following years along with the changes in tax revenue.

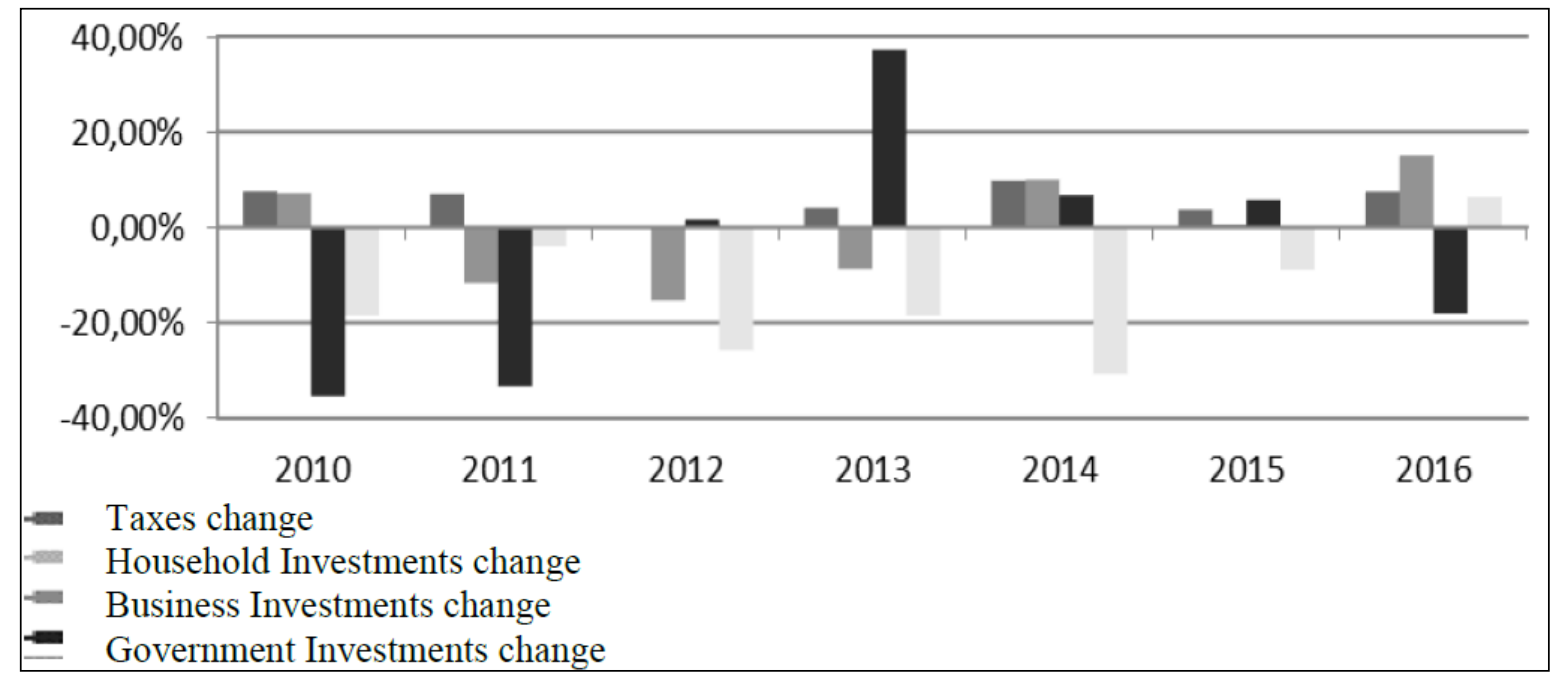

Figure 15. Annual change of Taxes and Investments by category 2010-2016

\section{Income Taxes and household investments}

In this section, the relation of households' tax revenues and investments in Greece for the period 2002-2016 is examined. As shown in the below Figure 16, by 2010 there was a relative stability of tax revenues as a proportion of GDP, while after the years 2011-2012 income taxes increased significantly, but remained stable the years after. On the other hand, changes in households' investments are much greater. With the exception of 2005, investments increased until 2008 when they began to reduce compare to the GDP and finally they fell from $13.3 \%$ in 2007 to $2.8 \%$ in 2016. 


\section{Macrothink}

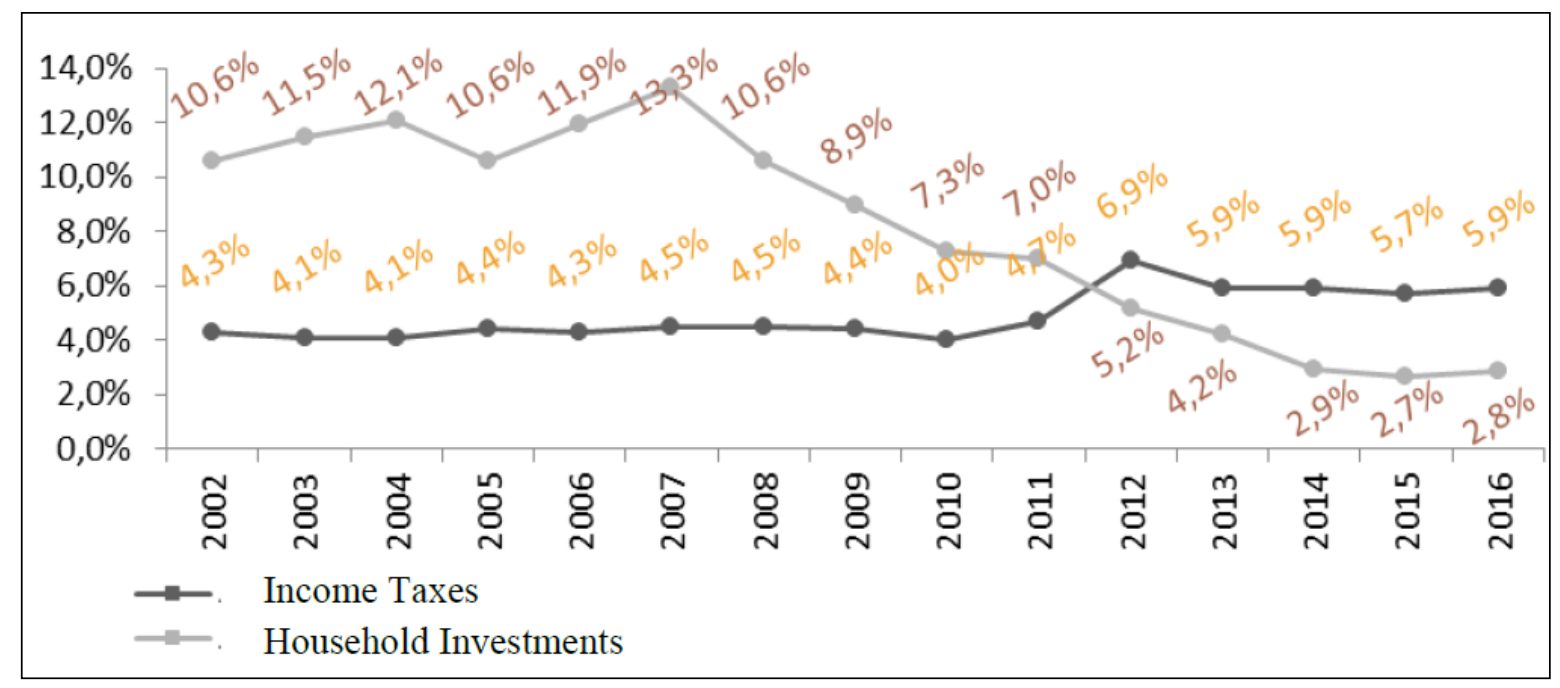

Figure 16. Income taxes and household investments

The Figure 17 below shows the percentage of annual changes in income taxes and household investments. The changes in the income tax were more mild with the exception of the years 2011-2012 where the rates increased highly. On the other hand, the fluctuations in household investments were greater throughout the period under consideration. As shown by the trend of the two sizes, investments in total had been reduced (average reduction $-7.9 \%$ ) and income taxes show little upward trend from 2003-2016, with an average annual growth of $3.1 \%$

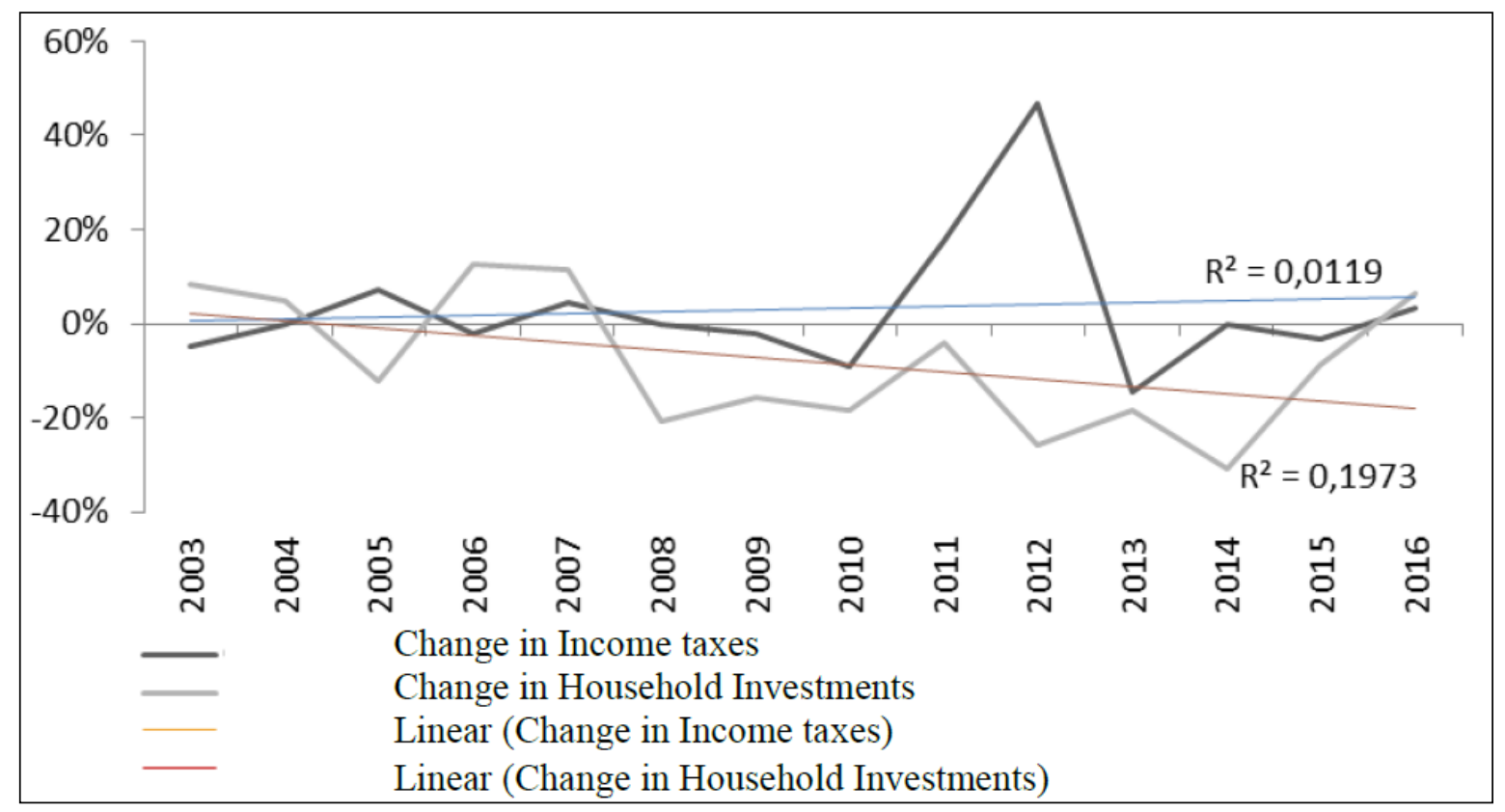

Figure 17. Annual change of Income Taxes and Household Investments 


\section{Macrothink}

\section{Corporate income taxes and business investments}

Business investments from 2002 to 2005 decreased, followed by a two-year upward trend. Since then, and with the exception of 2010 show a downward route up to 2016, where in relation to the previous year increased. On the other hand, corporate income taxes in 2005 increased compared to the two previous years, followed by a downward trend, which has stabilized in 2009-2010, and a decrease again in 2013. The last three years, taxes on company profits increased.

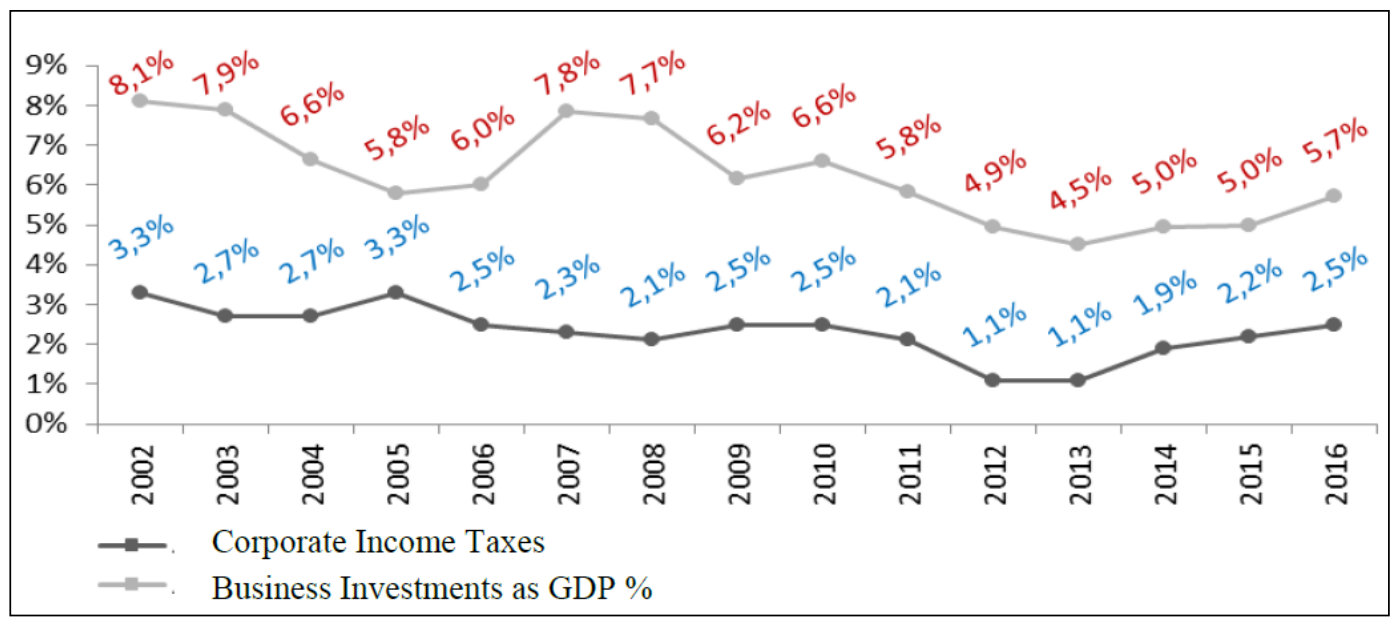

Figure 18. Corporate Income Taxes and Business Investments

Examining the annual changes in two sizes for the period 2002-2016, it is noted that after 2011 the changes in taxes were very high and especially in 2012 the decrease was $47.6 \%$, while in 2014 there has been an increase of $72.7 \%$. The average annual increase for the whole period was $1.48 \%$. Several variations occurred in the business investments, but without showing such extreme changes. Nevertheless, the average annual decrease in corporate investments was, $-1.56 \%$ for the whole period 2002-2016 (Figure 19).

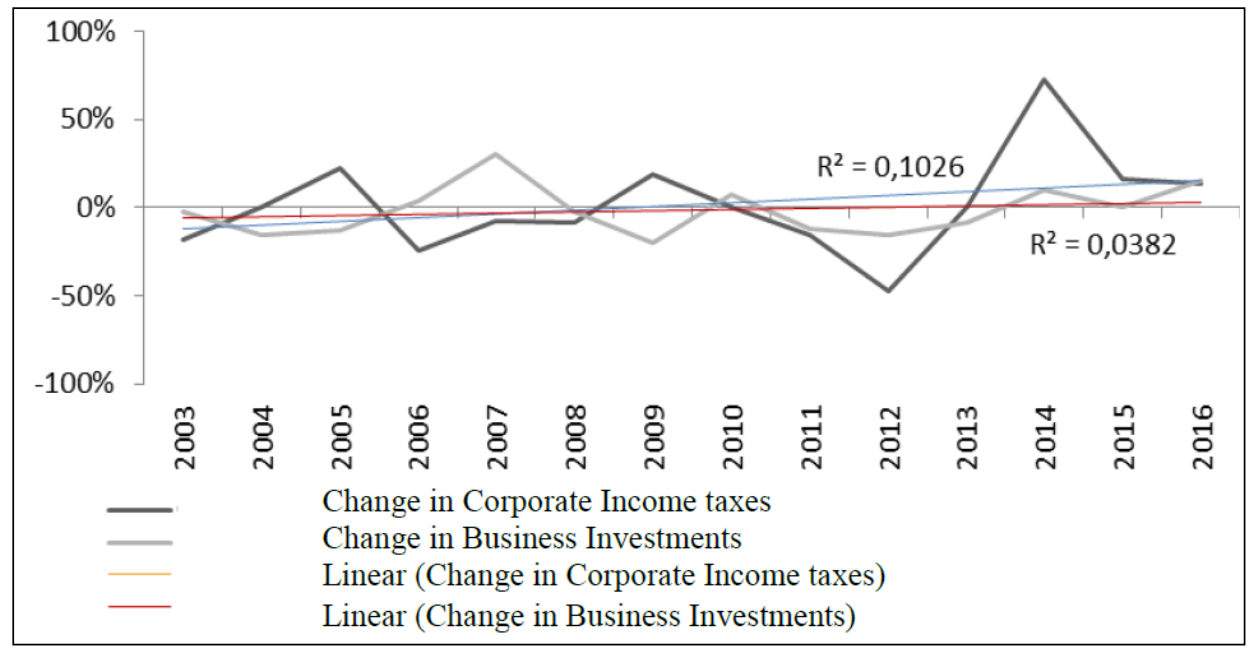

Figure 19. Annual corporate tax changes and corporate investments 
Comparing the changes in taxation and investments, we realize several differences between the years before and during the crisis. From 2002 to 2009 the taxation had average annual reduction of $1.2 \%$ (for the profits of the companies $-2.6 \%$ ), while in the next few years there has been an increase of $5.2 \%$ on average. The reductions of investments were smaller in the period before the crisis, $(-1.2 \%)$ on average, while the following years was considerably higher reaching $-7.2 \%$. During the crisis the average reduction in business investments was the smallest among the three categories, but even less than the previous period (Table 3).

Table 3. Average change of taxes and investments

\begin{tabular}{|l|l|l|l|}
\hline & AVE 2002-2016 & AVE 2002-2009 & AVE 2010-2016 \\
\hline Change in Taxes & $2.2 \%$ & $-1.2 \%$ & $5.2 \%$ \\
\hline Change in Corporate Taxes & $1.5 \%$ & $-2.6 \%$ & $5.0 \%$ \\
\hline Change in Investments & $-4.4 \%$ & $-1.2 \%$ & $-7.2 \%$ \\
\hline Change in Business Investments & $-1.6 \%$ & $-2.7 \%$ & $-0.6 \%$ \\
\hline Change in Government Investments & $-0.7 \%$ & $3.8 \%$ & $-4.5 \%$ \\
\hline Change in Household Investments & $-7.9 \%$ & $-1.6 \%$ & $-13.5 \%$ \\
\hline
\end{tabular}

\section{Conclusions}

The role of taxation on economic development was examined in the present study. Tax revenue is one of the main sources of revenue for the State and its role in the smooth functioning of an economy is of particular importance. At the same time, the structure of taxes is a good indicator of the development level of each country, because countries which rely more on indirect taxes are regarded to be less developed than countries relying on direct taxes. While the role of taxes in the functioning of the state is of significant importance, its relationship with the development is an extensively searched field but at several points unclear. Many theories and hypotheses have been formulated and researches have been carried out regarding the structure of the tax system and the ideal taxation to maximize the benefits to a society and an economy and also leading to development. However, because development is a dynamic concept and the tax system is characterized by complexity which interacts with many factors, we may not conclude to an unambiguous answer.

Greece is in a difficult position in the Global Competitiveness Index from 2008 onwards, while tax evasion is estimated to $8.8 \%$ of GDP.

The Greek tax system does not contribute to competitiveness improvement. Instead of shaping a fairer tax system by broadening the tax base, and by reducing the rate of corporate taxes, the increased trend changes in tax levies continues. The need to raise revenue has led to increase indirect taxes, extremely high as proportion to the total taxes as a percentage of GDP.

Taxation is also an important parameter for the development of enterprises, since it affects to a great extent the investment decisions, determines the course of specific sectors and the level of tax compliance (Baranová \& Janíčková, 2012; Venter \& Clercq, 2007; Vlachos, et al., 
2011; Helhel \& Varshalomidze, 2015). The negative impact of the corporate tax burden on economic development has been detected in various researches. The structure of the tax system may not only lead to an increase in revenue for the state but also to strengthen development (Baranová \& Janíčková, 2012; Bernardi, 2013; Widmalm, 2001).

The crisis of 2008 has not only affected negatively the tax revenues, but also reduced significantly the production of the country, highlighting the problems of the tax system, such as complexity and overregulating tax legislation, corruption, inefficiency of public administration. While the tax revenues seem to gradually increase, the fact of reduced revenue from direct taxes, especially from the taxation of business, combined with the increased tax evasion, do not give assurance to optimism. This observation is corroborated by the reduction of the gross operating surplus contribution to GDP, which consistently goes decreased.

Expenditures on R\&D in Greece are at a very low level as a proportion of GDP, which altogether from all areas do not exceed 1\% of GDP, while investments from 2008 and after are significantly declined. Especially the business investments in recent years count for about $5 \%$ of GDP. The value of investments is crucial for the development, while the negative impact of corporate taxation on investment and innovation has been confirmed by various empirical investigations (Gordon \& Lee, 2005; Baranová \& Janíčková, 2012; Helhel \& Varshalomidze, 2015).

Comparing the changes between tax revenues and investments for the period 2002-2016 it seems that there is a negative relationship between them, since taxes on average per year had increased (which is created after the beginning of the crisis), and investments were reduced, which was intensified after 2010. The period with a gradual fall in investments is the six-year 2007-2012, while the next years the proportion to the GDP has been stabilized. However, from 2009 onwards there has been a gradual increase in tax revenue as a proportion of GDP. For the period 2002-2016 taxes had an average annual growth of 2.2\%, which was established in the period during the crisis (average annual growth 5.2\%), since the years before crisis the average taxes per year fell by $-1.2 \%$. On the other hand, the total investments decreased at an annual average $-4.4 \%$, with significant worsening during the crisis. While the period 2002-2009 the total investments decreased by $-1.2 \%$ on average annually, the period after 2009 the annual reduction was $-7.2 \%$.

Similar is the course of income taxes and investments of households. From 2007 the fall in investment by households begins, which continued until 2015. In the period 2002-2016 the average annual reduction in households' investments was $-7.9 \%$, with the negative changes accelerated during the crisis, as in the period 2010-2016 when the average annual reduction was $-13.5 \%$, while in the previous period was $-1.6 \%$. In 2012 the income taxes of households increased as a percentage of GDP, reaching $6.9 \%$, from $4.7 \%$ in the previous years. In the last three years, they have been stabilized as a proportion of GDP at a considerably higher level than it was in 2002-2010 period (around 5.9\%).

The correlation between taxes on corporate profits and business investments was found negative, although there have been lower changes as percentage of the GDP in both sizes and 
in relation to the economy as a whole. This result claims in effect that Greece has been on the downward part of the household and business Laffer curve (Papp and Takáts, 2008). The changes on the corporate taxes, are not so extreme from year to year as a proportion of GDP, while the period before the crisis there has been a reduction of $-2.6 \%$ on average each year. The period during the crisis, the ratio to GDP varied greatly, with annually substantial increase, forming the average annual change to 5\%. On the other hand, the period 2010-2016 the percentage of investments to GDP, remained low, having average annual change $-0.6 \%$, the lowest in relation to other sectors of the economy and well below the previous period (2002-2009) which was $-2.7 \%$.

Characteristic of the course of these two sizes is the increasing tendency of taxes during the crisis, in contrast with the previous period when a reduction in taxes and in investments occurred, a phenomenon which culminated after 2010. Until 2009 the government maintained a positive growth rates on investment (average annual increase of 3.8\%) while businesses and households, not initiated respectively in this field.

In the case of households, until 2007 there is a general upward trend in investments, but in 2008, the taxes and levies culminating and was the beginning of the economic crisis and there has been a decrease in investments of $-20.7 \%$, which along with the high reduction in 2009 formed a negative average for the $2008-2016$ period. The increase in taxation, the beginning of the financial crisis, accompanied by the turbulence in the banking system and the significant reduction of loans, the reductions in income and the increase of uncertainty, seem to be the main factors of investment slashing curtailment by households.

The existence of positive or negative relationship from the changes in taxes and investments, is not absolutely clear in the present work, because of deferred timing between taxation and the impact on investments. As a first conclusion we can say that the fiscal framework of Greece needs a certain stability so its effectiveness does not be affected by the continuous changes.

It has been ascertaining the negative link between investment and tax burden on businesses and households. It is also proved that Government Investments do not have the expected return neither the proper management. Given that the country is in a constant state of recession and expects the economy to recover from the business investments, and up to a point from Household investments, it is obvious that a reduction in the tax burden on business and on households can bring an increase in investments.

The formulation of concrete proposals for tax reform is a task of officials responsible for the country's economic policy. It is clear however, that measures should be taken to strengthen the competitiveness of the Greek companies, especially in specific sectors which contribute significantly to the economy. Besides, tax reforms to reduce the complexity and to restore security and justice with measures, to combat tax evasion and broadening the tax base, to reduce the tax burden on the same taxpayers' groups are absolutely essential.

A limitation of the present study is that it is restricted in presenting the trend/evolution of taxes and investments, and not analyze thorough their relationship. Future research should 
present regression results, the value for the coefficients and the p-value or t-statistics for the results. Besides, appropriate time series model might be considered for further study of taxation and investment relation.

\section{References}

Arnold, J. (2008). Do Tax Structure Affect Aggregate Economic Growth? Empirical Evidence from a Panel of OECD Countries, s.l.: Economics Department Working Papers. No. 643. ECO/WKP(2008) 51. https://doi.org/10.1787/236001777843

Baranová, V., \& Janíčková, L. (2012). Taxation of Corporations and Their Impact on Economic Growth: The Case of EU Countries. Journal of Competitiveness, 4(4), 96-108. https://doi.org/10.7441/joc.2012.04.07

Bernardi, L. (2013). Recent findings regarding the shift from direct to indirect taxation in the EA-17, s.1.: MPRA Paper No. 47877.

Canavire-Bacarreza, G., Martinez-Vazquez \& Vulovic, V. (2013). Taxation and Economic Growth in Latin America, s.1.: IDB WP No 431.

ELSTAT (2017). Greek Statistics Services. [Online] Available at: http://www.statistics.gr/el/statistics/-/publication/SEL15/- [Accessed 20 February 2018].

Engen, E. M., \& Skinner, J. (1996). Taxation and Economic Growth, Cambridge: National Bureau of Economic Research Working Paper 5826.

Eurostat (2016). Eurostat. [Online] Available at:

http://ec.europa.eu/eurostat/statistics-explained/index.php/Glossary:Income_approach [Accessed 26 February 2018].

Eurostat (2017). Eurostat. [Online] Available at:

http://ec.europa.eu/eurostat/statistics-explained/index.php/Tax_revenue_statistics\#Direct_tax es_increased_in_2016.2C_while_indirect_taxes_remained_stable_and_social_contributions_ decreased [Accessed 22 February 2018].

Eurostat (2018). Eurostat. [Online] Available at:

http://ec.europa.eu/eurostat/web/government-finance-statistics/data/main-tables [Accessed 20 February 2018].

Gordon, R. H., \& Lee, Y. (2005). Tax Structure and Economic Growth. Journal of Public Economics, 89, 1027-1043. https://doi.org/10.1016/j.jpubeco.2004.07.002

Helhel, Y., \& Varshalomidze, M. (2015). Determinants Of Tax Attitude And Tax Compliance Among Small And Medium Enterprises (SMEs) In Tourism Industry: A Survey Study In Georgia. Archives of Business Research, 3(5), 14-23. https://doi.org/10.14738/abr.35.1495

Kitsopoulos, H. (2016). ABC I. T.. [Online] Available at: http://www.abcit.gr/index.php/news-feeds/vat-greece-history [Accessed 21 February 2018].

Koester, R. B., \& Kormendi, R. C. (1989). Taxation, Aggregate Activity and Economic 


\section{Macrothink}

Business and Economic Research

ISSN 2162-4860

2018, Vol. 8, No. 3

Growth: Cross-Country Evidence on Some Supply-Side Hypotheses. Economics Inquiry, 27(3), 367-386. https://doi.org/10.1111/j.1465-7295.1989.tb02011.x

Marsden, K. (1983). Links between taxes and economic growth: some empirical evidence, s.l.: World Bank Staff Working Papers no. 605.

Papp, T. K., \& Takáts, E. (2018). Tax Rate Cuts and Tax Compliance-The Laffer Curve Revisited, IMF Working Paper. Policy Development and Review Department, International Monetary Fund, 1-20.

Ragin, C. C. (1987). The Comparative Method: Moving Beyond Qualitative and Quantitative Strategies. University of California Press.

Stoilova, D. (2017). Tax structure and economic growth: Evidence from the European Union. Contaduría y Administración, 62, 1041-1057. https://doi.org/10.1016/j.cya.2017.04.006

Tanchev, S. (2016). The role of the proportional income tax on economic growth of Bulgaria. Ikonomicheski Izsledvania, 25(4), 66-77.

Venter, J., \& Clercq, B. (2007). A three-sector comparative study of the impact of taxation on small and medium enterprises. Meditari Accountancy Research, 15(2), 131-151.

https://doi.org/10.1108/10222529200700015

Vlachos, T., Diakomihalis, M., \& Lagos, D. (2011). Taxation and Competitiveness in the Hotel branch: The case of 4 and 5 star hotels of Kos island, Greece. Journal of Management Sciences and Regional Development, 7, 123-140.

Widmalm, F. (2001). Tax Structure and Growth: Are Some Taxes Better than Others? Public Choice, 107, 199-219. https://doi.org/10.1023/A:1010340017288

\section{Copyright Disclaimer}

Copyright for this article is retained by the author(s), with first publication rights granted to the journal.

This is an open-access article distributed under the terms and conditions of the Creative Commons Attribution license (http://creativecommons.org/licenses/by/3.0/). 